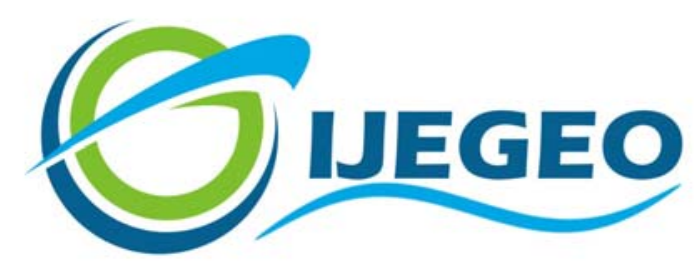

International Journal of Environment and Geoinformatics (IJEGEO) is an international, multidisciplinary, peer reviewed, open access journal.

\title{
The Effect of the Peak Discharges of River Danube on the Strait of Istanbul (Bosphorus)
}

\section{Yavuz KARSAVRAN, Tarkan ERDİK, Zeynep Özge KURT}

\author{
Chief in Editor \\ Prof. Dr. Cem Gazioğlu \\ Co-Editors \\ Prof. Dr. Dursun Zafer Şeker, Prof. Dr. Şinasi Kaya, \\ Prof. Dr. Ayşegül Tanık and Assist. Prof. Dr. Volkan Demir \\ Editorial Committee (August 2020)
}

Assos. Prof. Dr. Abdullah Aksu (TR), Assit. Prof. Dr. Uğur Algancı (TR), Prof. Dr. Bedri Alpar (TR), Prof. Dr. Lale Balas (TR), Prof. Dr. Levent Bat (TR), Prof. Dr. Paul Bates (UK), İrşad Bayırhan (TR), Prof. Dr. Bülent Bayram (TR), Prof. Dr. Luis M. Botana (ES), Assos. Prof. Dr. Gürcan Büyüksalih (TR), Prof. Dr. Nuray Çağlar (TR), Prof. Dr. Sukanta Dash (IN), Dr. Soofia T. Elias (UK), Prof. Dr. A. Evren Erginal (TR), Assoc. Prof. Dr. Cüneyt Erenoğlu (TR), Dr. Dieter Fritsch (DE), Prof. Dr. Çiğdem Göksel (TR), Prof.Dr. Lena Halounova (CZ), Prof. Dr. Manik Kalubarme (IN), Dr. Hakan Kaya (TR), Assist. Prof. Dr. Serkan Kükrer (TR), Assoc. Prof. Dr. Maged Marghany (MY), Prof. Dr. Michael Meadows (ZA), Prof. Dr. Nebiye Musaoğlu (TR), Prof. Dr. Masafumi Nakagawa (JP), Prof. Dr. Hasan Özdemir (TR), Prof. Dr. Chryssy Potsiou (GR), Prof. Dr. Erol Sarı (TR), Prof. Dr. Maria Paradiso (IT), Prof. Dr. Petros Patias (GR), Prof. Dr. Elif Sertel (TR), Prof. Dr. Nüket Sivri (TR), Prof. Dr. Füsun Balık Şanlı (TR), Prof. Dr. Uğur Şanlı (TR), Duygu Ülker (TR), Prof. Dr. Seyfettin Taş (TR), Assoc. Prof. Dr. Ömer Suat Taşkın (US), Dr. İnese Varna (LV), Dr. Petra Visser (NL), Prof. Dr. Selma Ünlü (TR), Assoc. Prof. Dr. İ. Noyan Yilmaz (AU), Prof. Dr. Murat Yakar (TR), Assit. Prof. Dr. Sibel Zeki (TR) 


\title{
Research Article
}

\section{The Effect of the Peak Discharges of River Danube on the Strait of Istanbul (Bosphorus)}

\author{
Yavuz Karsavran ${ }^{1,2^{*}}$ iD , Tarkan Erdik ${ }^{3}$ iD , Zeynep Özge Kurt ${ }^{4}$ iD \\ ${ }^{1}$ ITU, PhD Candidate, Civil Engineering Faculty, Hydraulics and Water Resources Engineering, Ayazağa Campus 34469 Maslak, Istanbul TR \\ 2 Şişli Vocational School, Lecturer, Technology of Buildings, 34469 Maslak, Istanbul TR \\ 3 ITU, Associated Professor, Civil Engineering Faculty, Hydraulics and Water Resources Engineering, Ayazağa Campus 34469 Maslak, Istanbul TR \\ ${ }^{4}$ Erzincan Binali Yıldırım University, Engineering Faculty Civil Engineering Department, Yalnızbağ Campus, 24100 Erzincan TR
}

How to cite: Karsavran et al., (2020). The Effect of the Peak Discharges of River Danube on the Strait of Istanbul (Bosphorus), International Journal of Environment and Geoinformatics (IJEGEO), 7(2): 108-113. DOI: 10.30897/ijegeo.701241

\begin{abstract}
The Strait of Istanbul (Bosphorus: SoI) is the meeting point of Black Sea and Marmara Sea. It is under influence of many hydrological, oceanographical and meteorological variables. Clearly, it is known that River Danube discharge reaches to the Sea of Marmara via SoI. The approximate distance between outlet of River Danube and northern end of the SoI is nearly $500 \mathrm{~km}$. In this study, the influence of the peak river Danube discharges (higher than $11000 \mathrm{~m}^{3} / \mathrm{s}$ ) on the SoI is investigated by using dataset of TAISEI Corporation, ISKI, Turkish State Meteorological Service and GRDC, Grains Research and Development Corporation. To this end, the power spectra of River Danube is calculated and compared with those of water level, surface layer water salinity and finally, surface water temperature data at the northern end of the SoI. In addition, the time series of water temperature, water salinity, and water level of the northern end of the SoI is examined together with time series of River Danube discharge between 1 st Oct 2004 and 31 st Sept 2005. The validation is performed by checking wind speed, air pressure and precipitation data on the SoI during that time.
\end{abstract}

Keywords: The Strait of Istanbul (Bosphorus), Water Level, Power Spectra, River Danube, Lag Time, Black Sea

\section{Introduction}

There are various studies in the literature that deal with hydrodynamics of the Strait of Istanbul (Bosphorus: SoI, Sur et al., 1994; Özsoy et al., 1996, 1998; Doğan et al., 1998; Oğuz T., 2005; Jarosz et al., 2011; Öztürk et al., 2012; Gündüz and Özsoy, 2016; Tutsak, et al., 2016; Stanev et al., 2017; Beji and Erdik, 2018; Erdik et al., 2018; Erdik et al., 2019a; Erdik et al., 2019b, Gündüzi et al., 2020; Saçu et al., 2020). However, there is only a few studies in the literature that deal with constructing the relationship of River Danube with the northern Strait of Istanbul. The conclusions drawn in those studies are mainly based on limited dataset and rough estimations. Sur et al., (1994) used monthly mean discharge of River Danube and monthly mean salinity of SoI to find out effects of River Danube on SoI. They roughly estimated the lag time approximately between 1-2 months. Similarly, Yüksel et al., (2008) observed the monthly mean water level of northern SoI and River Danube discharge and indicated 2-month lag time. Lastly, Şen et al., (2019) demonstrated a linear relationship between the 2-month-ahead monthly flow of the SoI, computed by a numerical model, and River Danube flow observations. In this study, a-year long 4 different higher resolution datasets (with a 1-day sampling rate) are used to investigate the relationship between River Danube and northern SoI. Those are discharge of River Danube and surface water temperature, surface water salinity, water level at northern end of SoI. In addition to this, wind speed, air pressure and precipitation data on SoI are also checked for validation.

Table 1- Measurement locations and durations.

\begin{tabular}{|c|c|c|c|c|}
\hline Stations & Measured Period & $\begin{array}{l}\text { Measured } \\
\text { Characteristics }\end{array}$ & $\begin{array}{l}\text { Time } \\
\text { Interval }\end{array}$ & Locations \\
\hline St E & $22.09 .04-05.01 .06$ & $\begin{array}{l}\text { Water level, } \\
\text { salinity and } \\
\text { temperature }\end{array}$ & Hour & $41^{0} 1213^{\prime \prime} \mathrm{N}, 29^{0} 05^{\prime} 54^{\prime \prime} \mathrm{E}$ \\
\hline St G & 19.11.04-05.01.06 & $\begin{array}{l}\text { Wind speed, } \\
\text { air pressure }\end{array}$ & $10 \mathrm{~min}$ & $41^{0} 24^{\prime \prime} \mathrm{N}, 29^{0} 6^{\prime \prime} \mathrm{E}$ \\
\hline St Sarıyer & 01.01.04-31.12.05 & Precipitation & daily & $41^{0} 08^{\prime} 47^{\prime \prime} \mathrm{N}, 29^{0} 03^{\prime} 0.7^{\prime \prime} \mathrm{E}$ \\
\hline St K0 & 01.01.04-31.12.05 & Salinity & monthly & $41^{0} 13.50^{\prime} \mathrm{N}, 20^{\circ} 08^{\prime} \mathrm{E}$ \\
\hline St Ceatal Izmail & 01.01.04-31.12.05 & Discharge & daily & $45^{0} 21^{\prime} 67^{\prime \prime} \mathrm{N}, 28^{0} 71^{\prime} 67^{\prime \prime} \mathrm{E}$ \\
\hline
\end{tabular}




\section{Data and Study Area}

All data measurements and durations are clearly depicted on Table 1.

Wind speed, atmospheric pressure, water level, temperature and salinity were monitored in St. E and G by TAISEI Corporation, JAPAN, on behalf of General Directorate of Marmaray Project of Ministry of Transportation, General Directorate of Ports, Airports and Railways Construction of Turkey (Fig. 1a). On the other hand, water salinity measured in K0 by Istanbul Water and Sewerage Administration (ISKI) and precipitation measured by Turkish State Meteorological Service in Saryyer Station are also employed. River Danube discharge data were measured for 2004-2005 by Grains Research and Development Corporation (GRDC, Fig. 1b). Locations of the aerial view of River Danube and SoI are clearly shown in Fig 1c.

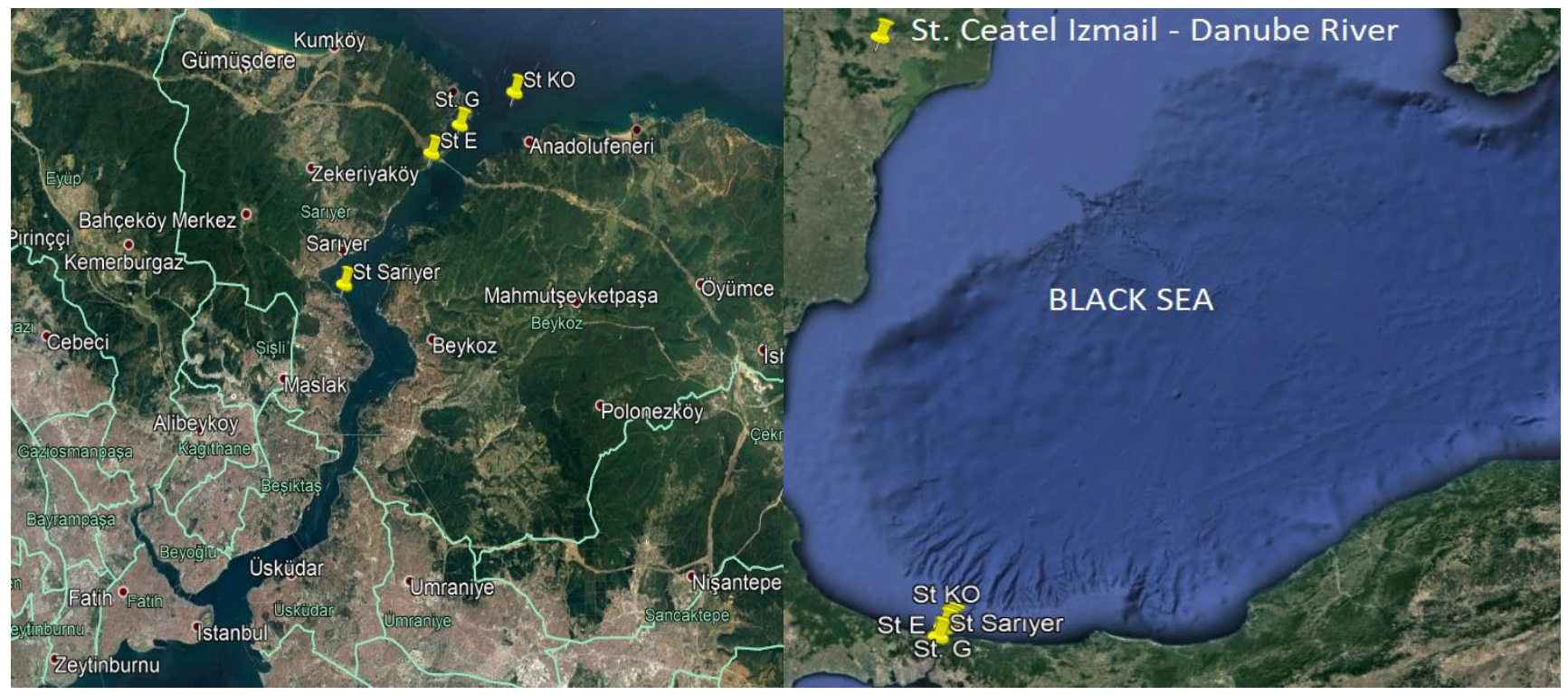

b

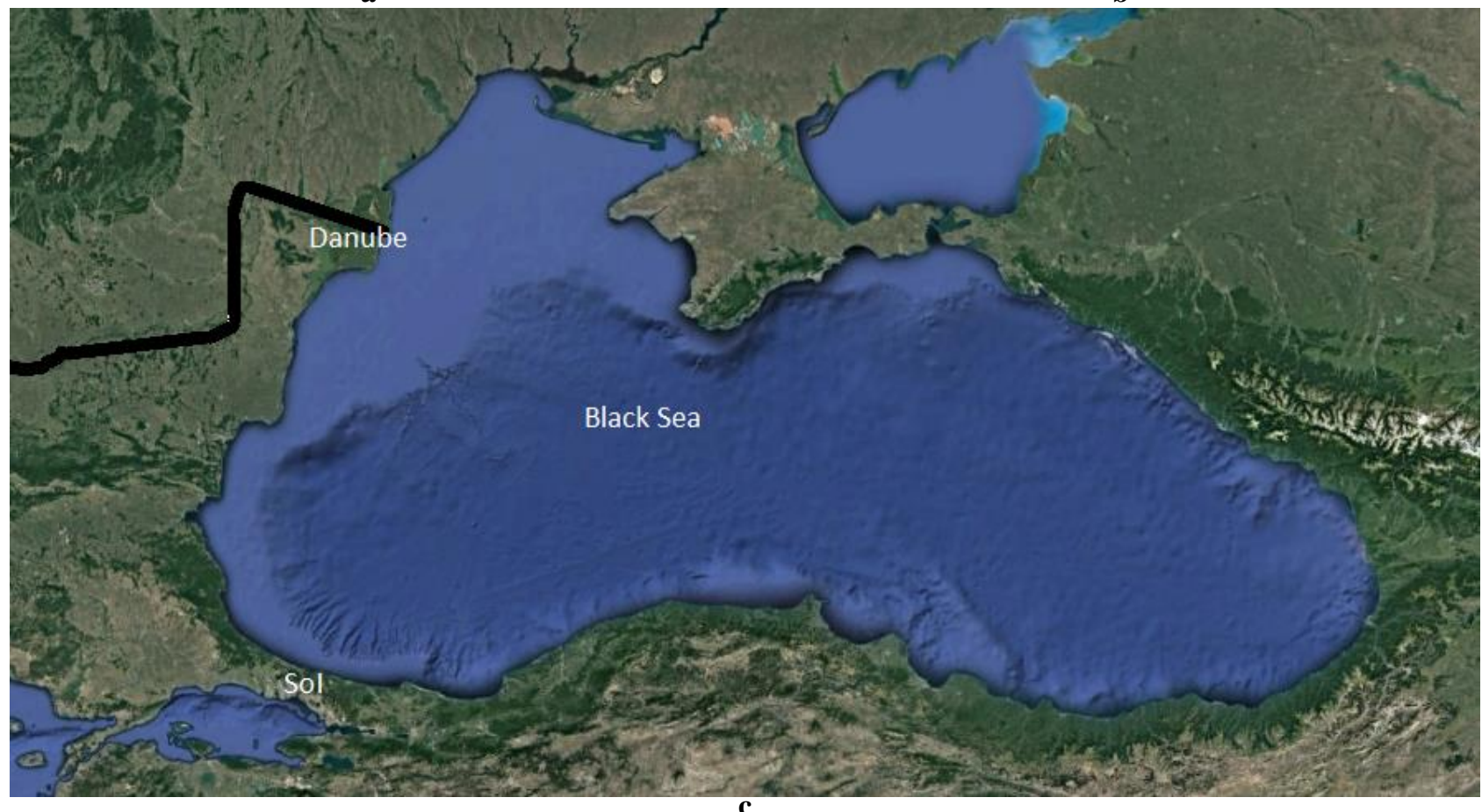

Fig. 1- General views of a) Station G, E, Sariyer and KO on SoI and b) Station Ceatel Izmail on River Danube, c) Locations of River Danube and SoI.

\section{Methodology and Results}

The power spectra of River Danube (Fig. 2a) is plotted by using discharge data of one year and compared with those of water level (Fig. 2b), surface layer water salinity (Fig. 2c) and water temperature (Fig. 2d) at the northern end of SoI for the same period. As seen in Figs. 2 a-c, similar trends are observed between power spectra of River Danube and those of water level and surface water salinity, especially with periods of 4, 3, 2 and 1 months, depicted in red solid ellipses. 


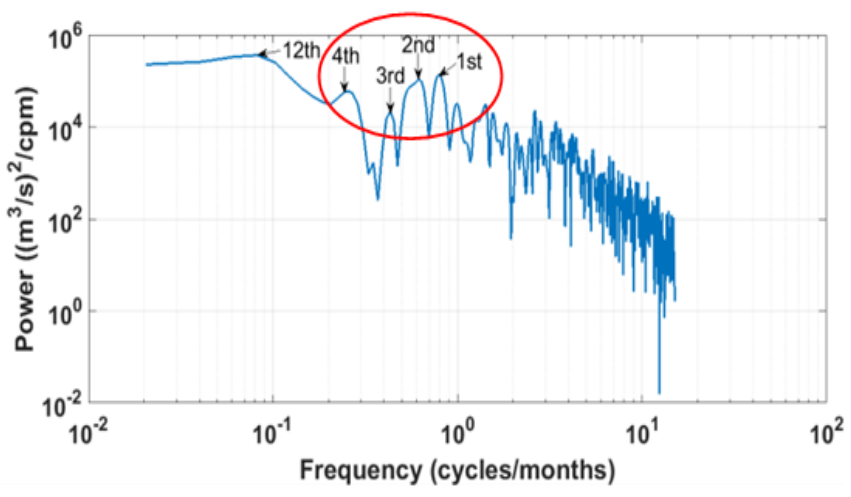

$\mathbf{a}$

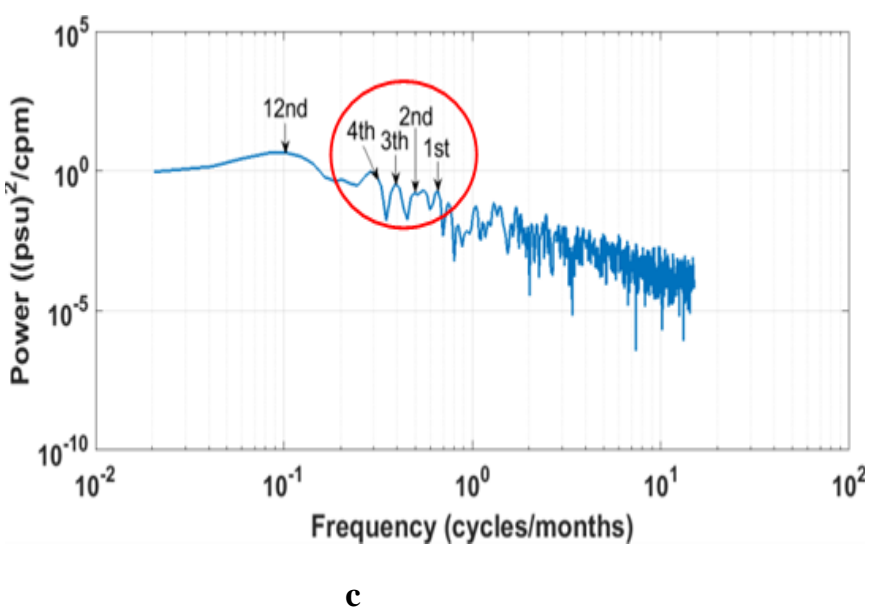

Fig. 2. Power spectras of (a) River Danube, (b) water level, (c) surface water salinity, (d) surface water temperature at the northern end of the SoI.

The influence of River Danube on SoI is clearly visible on those graphs. In addition, surface temperature power spectra (Fig. 2d) also demonstrates similarity with River Danube but with a little difference; the 5-month period is observed there, which is considered to be caused by local meteorological conditions around the SoI.

Maximum runoff discharge occurs at the 2nd of May, 2005 (214th day of the year), depicted in solid square (Fig. 3a). Water temperature loses its sharpness (Fig. 3b) while it has to rise dramatically because of the summer season and salinity stays stable (Fig. 3c) while those should be on rise because of the high evaporation effect in July. A dramatic increase in 15th July 2005 (288th day of the year) is obviously seen on the northern water level (Fig. 3d). Özsoy et al., (1996) states that there are three main effects to force the mechanism of water level increase in SoI. These are incoming fresh water to the Black Sea, atmospheric pressure differences and wind setup. In addition, precipitation might also increase surface water level in Black Sea (Ünlüata et al., 1990). To ensure that there is no extraordinary atmospheric phenomenon on the related dates that affect the water level instead of Danube River Discharge, the time series of the northern and eastern (Figs. 4a-b) wind speeds, air

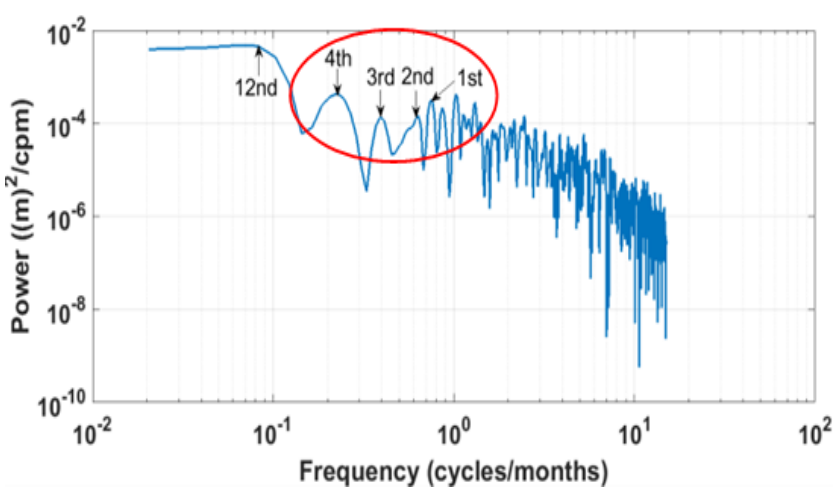

b

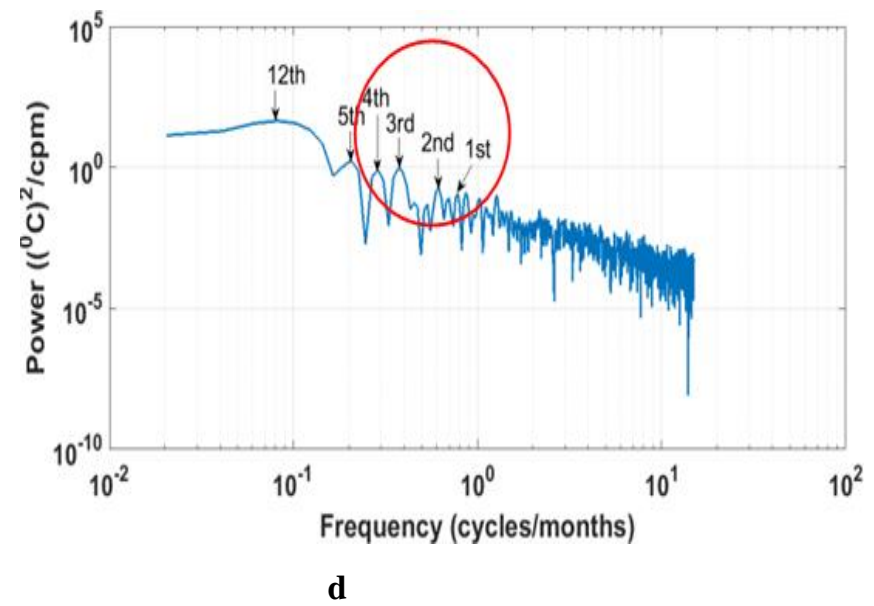

pressure differences (Fig. 4c) and finally daily precipitation from Sariyer meteorological station (Fig. 4d) are also checked, depicted in solid squares. Clearly, wind speeds, air pressure, precipitations are observed minimal level during that day. Eastern and northern wind speeds are observed to be $5.402 \mathrm{~m} / \mathrm{s}$ and $-0.432 \mathrm{~m} / \mathrm{s}$, respectively (Fig 4a-b). And air pressure (Fig 4c) is about $1010 \mathrm{hPa}$ and the precipitation is zero at that time (Fig. 4d). The period between the maximum discharge of River Danube (2nd of May, 2005) and the peak of the water level at northern end of SoI (15th of July, 2005) than the last study by Şen et al., (2019), estimated 2 months lag time, the highest one in the literature, Danube River to SoI.

The second maximum runoff discharge occurs at the 22nd of July, 2005 (295th day of the year), depicted in a solid ellipse (Fig.3a). A radical decrease is noticed both in surface water temperature (Fig. 3b) and surface salinity values (Fig. 3c) at the 27th of September, 2005, which clearly indicates the cold and fresh water impact of Maxima River Danube discharge on SoI. Additionally, water level of Northern SoI (Fig. 3d) shows a peak at the 27th (362nd day of the year) of indicates that the lag time is 74 days, which is higher 
September, 2005, which coincides with the decrease of surface water temperature and surface salinity, which depicts incoming high volume freshwater from Danube River. Those aforementioned indications clearly demonstrate the influence of River Danube on SoI. The period between the second peak discharge of River Danube (22nd of July, 2005) and the peak of the water level at northern end of SoI (27th of September, 2005) indicates that the lag time is 67 days. Eastern and northern wind speeds (Fig 4a-b) are observed to be $2.963 \mathrm{~m} / \mathrm{s}$ and $3.212 \mathrm{~m} / \mathrm{s}$, respectively. And air pressure (Fig. 4c) is $1017 \mathrm{hPa}$ while annual mean air pressure is $1012 \mathrm{hPa}$. The precipitation is about $0 \mathrm{~mm}$ on that time (Fig 4d). In conclusion, the only effect to explain water level rising in northern SoI (27th of September, 2005) is found to be River Danube discharge.
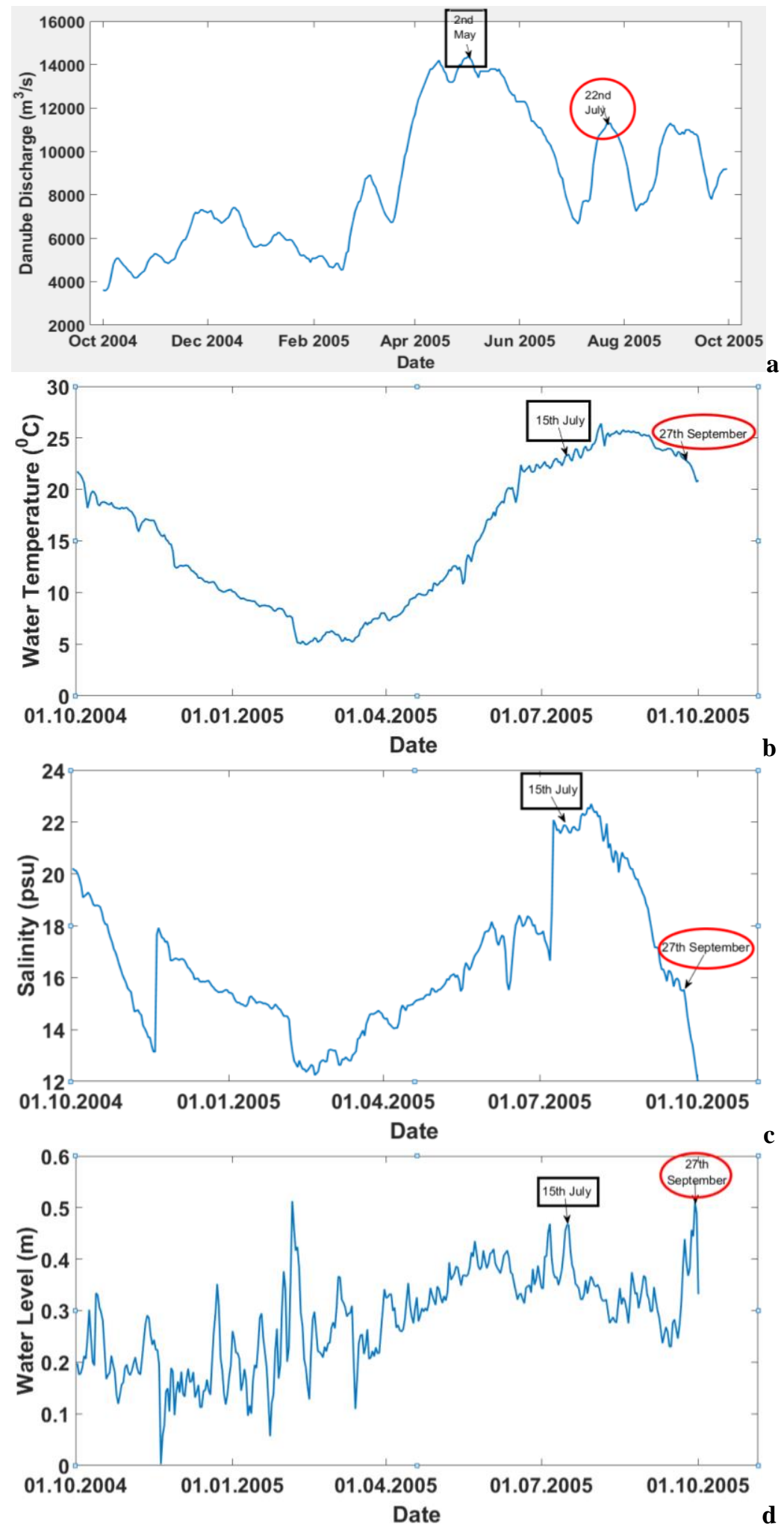

Fig. 3. Time series of (a) discharge values of Danube River, (b) Surface water temperature of SoI, (c) Salinity of SoI, (d) Northern water level of SoI. 

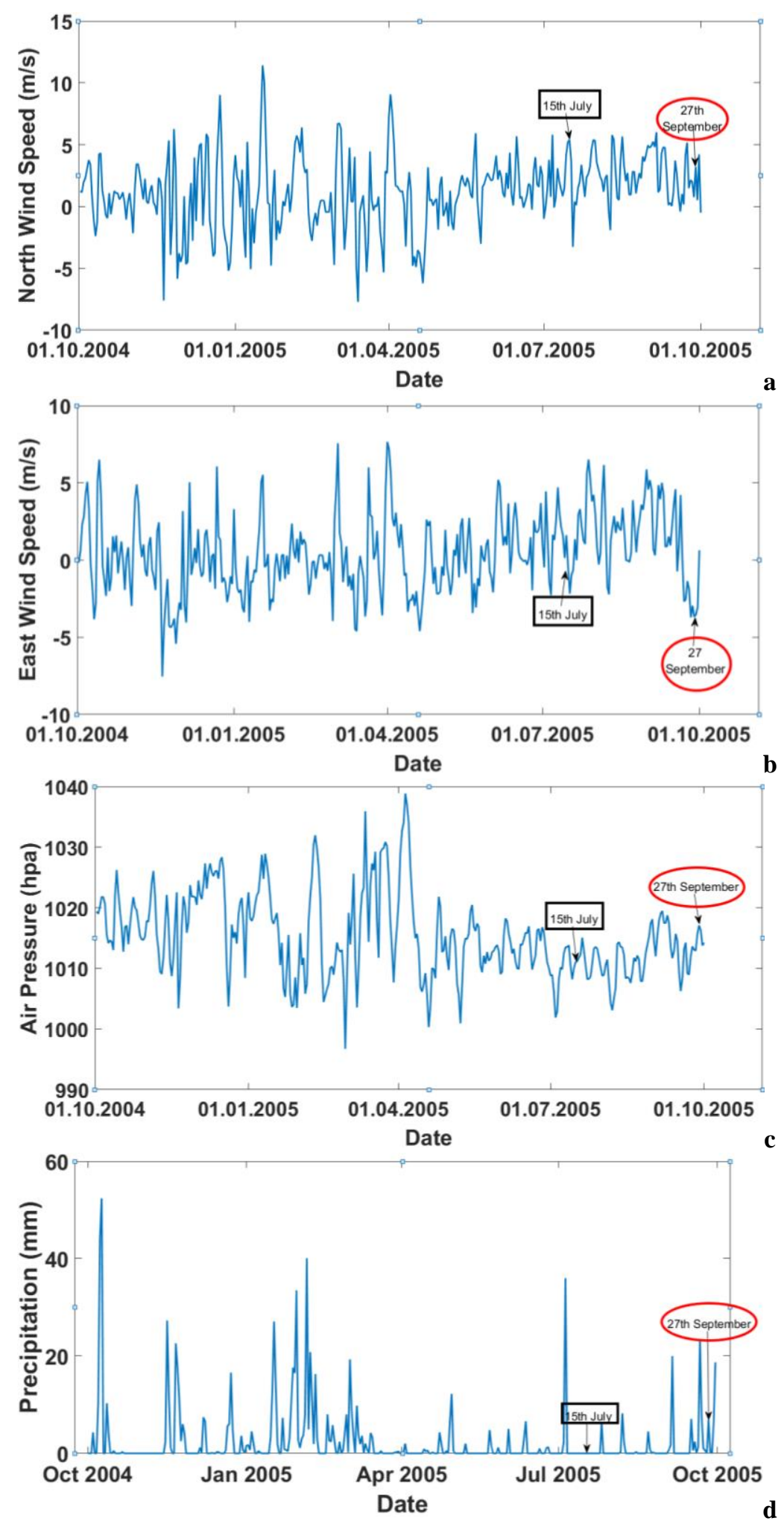

Fig. 4. Time series of (a) Northern wind speed, (b) Eastern wind speed, (c) Air Pressure of northern SoI, (d) Daily meteorological precipitation of Saryer station.

\section{Discussions and Conclusions}

Comparison of power spectra of River Danube discharge (Fig. 2a) and power spectra of water surface elevation, surface layer water salinity and water temperature of northern end of the SoI (Fig. 2b-d) obviously depicts that there is a correlation between Danube and SoI. Power density of River Danube on 4,3,2 and 1 months are clearly observed on power densities of water level, salinity and temperature of the northern end of the SoI.

Maximum runoff discharge of Danube on 2nd of May, 2005 (Fig 3a) cause maximum water level at the Northern end of SoI (Fig. 3d) in 15th July 2005. This means that the lag time is 74 days. The second peak discharge at 22nd of July reaches to the SoI in 27th of September, 2005 when the water level at the Northern 
end increases. That means the lag time is 67 days for that season.

The River Danube discharges which are under value of $\sim 11000 \mathrm{~m}^{3} / \mathrm{s}$ cannot be detectable on water level, salinity and temperature time series of SoI due to the local oceanographical and meteorological effects around SoI.

\section{Acknowledgements}

The authors wish to express their sincere thanks to GRDC (Grains Research and Development Corporation) and Mr. Thomas de Couet. TAISEI Corporation, General Directorate of Marmaray Project of Ministry of Transportation, General Directorate of Ports, Airports and Railways Construction of Turkey, Turkish State Meteorological Station and ISKI for their data processing contributions.

\section{References}

Beji, S., Erdik T. (2018). "Hydrodynamics and Modelling of Turkish Straits". Oil Spill along The Turkish Straits Sea Area; Accidents, Environmental Pollution, Socio-Economic Impacts and Protection, İstanbul, 79-90

Doğan, E., C. Gazioğlu, E. Okuş, I.E. Gönenç, H. Yüce., ZY. Yücel. (1998). Examination of the Pollution in the West Black Sea by Remote Sensing Technologies, Journal of Black Sea/Mediterranean Environment, 4(2), 89-101.

Erdik, T., Şen, O., Erdik, J. D., Öztürk, İ. (2018). LongTerm 3D Hydrodynamic Modeling and Water Surface Statistics in Marmara Sea. Marine Geodesy, 41(2), 126-143

Erdik, T., Şen, O., Öztürk, İ. (2019a). “3D Numerical Modeling of Exchange Flows in Golden Horn Estuary". J. Waterway Port Coastal Ocean Eng., 145(5).

Erdik, T., Şen, O., Öztürk, İ. (2019b). "Testing various scenarios to improve circulation in Golden Horn: A case study". Marine Pollution Bulletin, 146, 598-607.

Gündüz, M., E. Özsoy, 2016. On water transport variability of the Bosphorus Strait. In: The Sea of Marmara; Marine Biodiversity, Fisheries, Conservation and Governance, (Eds: E. Özsoy, M.N. Çağatay, N. Balkıs, N. Balkıs, and B. Öztürk), TÜDAV, 118-134.

Gündüz, M., Özsoy, E., Hordoir, R. (2020). A model of Black Sea circulation with strait exchange (20082018)., Geosci. Model Dev., 13, 121-138, 2020 DOI: 10.5194/gmd-13-121-2020

Jarosz, E., Teague, W. J., Book, J. W., Beşiktepe, Ş. (2011). "On flow variability in the Bosporus Strait." Journal Geophys Res, 116, C08038.

Oğuz, T (2005). "Hydraulic adjustment of the Bosporus exchange flow".Geophys Res Letters, 32, L06604.

Özsoy, E., Latif, M.A., Beşiktepe, Ş., Çetin, N., Gregg, M., Belekopytov, V., Goryachkin, Y., Vassile, D. (1998). "The Bosphorus Strait: exchange fluxes, currents and sea-level changes." In: Ivanov, L.I., Oğuz, T. (Eds.), Ecosystem Modeling as a
Management Tool for the Black Sea, NATO Science Series 2: Environmental Security, 1 and 2. Kluwer Academic Pub., Dordrecht, 367.

Özsoy, E., Latif, M.A., Sur, H.I., Goryachkin, Y., 1996. A review of the exchange flow regime and mixing in the Bosphorus Strait. Bulletin de l'Institut Oceanographique, Monaco, no. special, CIESM Science Series nu 2, 187-204.

Öztürk, M., Ayat, B., Aydoğan, B., Yüksel, Y. (2012). "3D Numerical modeling of stratified flows: case study of the Bosphorus Strait." Journal of Waterway, Port, Coastal, and Ocean Engineering, 138(5), 406419.

Saçu, Ş., Erdik, T, Stanev, E., Şen, O., Duricic, J., Öztürk, İ (2020) Hydrodynamics of Canal Istanbul and its impact in the northern Sea of Marmara under extreme conditions DOI: 10.1007/s10236-02001358-4

Şen, O., Saçu, Ş., Erdik, T., Duricic, J., Özturk, İ. (2019). Investigation of Northern Bosphorus Flow Structure with River Danube. 9th International Symposium on Atmospheric Sciences (ATMOS 2019).

Stanev, E., Grashorn, S., Zhang, Y.J. (2017). "Cascading ocean basins: numerical simulations of the circulation and interbasin Exchange in the AzovBlack-Marmara-Mediterranean Seas system". Ocean Dynamics, 67, 1003-1025.

Sur, H.I., Özsoy, E., Ünlüata, Ü., (1994). Boundary current instabilities, up welling, shelf mixing and eutrophication processes in the Black Sea. Progress in Oceanography 33, 249-302.

Tutsak, E., M. Gündüz., E. Özsoy, 2016. Sea level and fixed ADCP measurements from Turkish Straits System during 2008-2011. In: The Sea of Marmara; Marine Biodiversity, Fisheries, Conservation and Governance, (Eds: E. Özsoy, M.N. Çağatay, N. Balkıs, N. Balkıs, and B. Öztürk), TÜDAV, 62-78.

Ünlüata, Ü., Oğuz, T., Latif, M.A., Özsoy, E. (1990). "On the physical oceanography of Turkish Straits". In: Pratt, L.J. (Ed.), The Physical Oceanography of Sea Straits, NATO/ASI Series, Kluwer, Dordrecht, 25-60

Yüksel, Y., B. Ayat, M. N. Özturk, B. Aydoğan, I. Guler, E. O. Cevik, A. C. Yalciner. (2008). Responses of the stratified flows to their driving conditions. A field study. Ocean Engineering 35(13):1304-1321. 